\title{
Reflection on Mental Health System and Quality Assurance: Considering the Relevance of the Australian Experience for Indonesia
}

\section{NEIL FRAZER}

Pelayanan kesehatan jiwa di Australia telah berkembang menjadi pelayanan yang berorientasi pada komunitas dan sensitive terhadap kebutuhan dan hak klien dengan gangguan jiwa. Perkembangan ini mempunyai implikasi pada system kesehatan jiwa komunitas., kebijakan tentang kesehatan jiwa, legalisasi, pelayanan kesehatan jiwa, pelayanan pembauran, begitu pula implikasi terhadap praktek keperawatan. Perubahan dalam pelayanan kesehatan jiwa menuntut perawat untuk memiliki pengetahuan yang teoritis yang lebih baik dan kemampuan untuk melakukan praktek keperawatan secara professional.

Di Indonesia, kajian yang ekstensif tentang kebutuhan masyarakat dengan masalah kesehatan jiwa, sumber yang tersedia untuk memenuhi kebutuhan tersebut, serta keyakinan, nilai dan sikap tenaga professional kesehatan jiwa tentang ilmu kedokteran dan perilaku dari negara barat yang mempengaruhi pelayanan kesehatan jiwa, sangat diperlukan untuk pengembangan system kesehatan jiwa yang lebih efektif dan efesien.

Kata Kunci : Pelayanan kesehatan jiwa, pengembangan.

The mental health services in Australia have been developed to be more community based services and sensitive to the needs and rights of the mentally ill. This development has implications for mental health system and the community, mental health policy, legislation, mental health services, mainstreaming services as well as implications for nursing practice. The change in mental health services required the nurse to have the better theoretical knowledge and competence to practice professionally. In Indonesia, the extensive study on the needs of the people with mental health problem and the existing resource to meet those needs, as well as the current beliefs, values and attitudes held by mental health professionals towards the Western medical and behavioral science influence on mental health services is an important process in developing more efficient and effective mental health system.

Key word : The mental health service, developing. 